Nordic Journal of International Law 


\section{Nordic Journal of International Law}

Acta scandinavica juris gentium

Editor-in-Chief

Astrid Kjeldgaard-Pedersen

Co-Editors

Gudmundur Alfredsson, Jan Klabbers and Timo Koivurova

Book Review Editors

Michael Bogdan, Pål Wrange, Valentin Jeutner and Cecilia Bailliet

Managing Editor

Miriam Bak McKenna

Board of Trustees

Gudmundur Alfredsson, Jonas Bering Liisberg, Ole Spiermann

Editorial Board

Lauri Hannikainen, Frederik Harhoff, Tomas Heidar, Jan Helgesen, Thordis Ingadottir, Marie Jacobsson, Marja Lehto, Ulf Linderfalk, Gregor Noll, Inger Österdahl, Helge Seland, Kaija Suvanto, Thomas Winkler

\section{Advisory Board}

Michael Bogdan, Bengt Broms, Karin Bruzelius, Iain Cameron, Hans Corell, Gudmundur Eiriksson, Ole Espersen, Carl August Fleischer, Morten Kjaerum, Ole Lando, Göran Melander, Laurids Mikaelsen, Dag Mjaaland, Jakob Möller, Ann Marie Pennegard, Lars Adam Rehof, Allan Rosas, Martin Scheinin, Torben Svenné Schmidt, Geir Ulfstein

Volumes published in this journal are listed at brill.com/nord 


\title{
Nordic Journal of International Law
}

Acta scandinavica juris gentium

VOLUME 91 (2022)

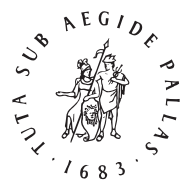 \\ B R I L L \\ N IJHOF F \\ LEIDEN | BOSTON
}




\section{Note to Contributors}

Authors are requested to arrange their manuscripts in accordance with the Journal's Instructions for Authors. Detailed Instructions for Authors can be obtained from the address below. Guidelines can also be found online at: brill.com/AuthorsInstructions/NORD.pdf.

Nordic Journal of International Law

Raoul Wallenberg Institute

University of Lund

P.O. Box 1155

S-221 05 Lund

Sweden

E-mail: njil@rwi.lu.se

Papers for consideration or books to be considered for review should be submitted online at: editorialmanager.com/nord.

Need support prior to submitting your manuscript? Make the process of preparing and submitting a manuscript easier with Brill's suite of author services, an online platform that connects academics seeking support for their work with specialized experts who can help. Go to https://authorservices.brill.com/.

Brill Open Access options can be found at brill.com/brillopen.

Typeface for the Latin, Greek, and Cyrillic scripts: "Brill”. See and download: brill.com/brill-typeface.

ISSN 0902-7351

E-ISSN 1571-8107

\section{Copyright 2022 by Koninklijke Brill NV, Leiden, The Netherlands}

Koninklijke Brill NV incorporates the imprints Brill, Brill Nijhoff, Brill Hotei, Brill Schöningh, Brill Fink, Brill mentis, Vandenhoeck \& Ruprecht, Böhlau Verlag and V\&R Unipress.

All rights reserved. No part of this publication may be reproduced, translated, stored in a retrieval system, or transmitted in any form or by any means, electronic, mechanical, photocopying, recording or otherwise, without prior written permission from the publisher. Requests for re-use and/or translations must be addressed to Koninklijke Brill NV via brill.com or copyright.com.

Brill has made all reasonable efforts to trace all rights holders to any copyrighted material used in this work. In cases where these efforts have not been successful the publisher welcomes communications from copyright holders, so that the appropriate acknowledgements can be made in future editions, and to settle other permission matters.

This journal is printed on acid-free paper and produced in a sustainable manner. 